\title{
Synthetic chalcone derivatives inhibit cytokine secretion via inhibition of ERK and JNK pathways in human U937 macrophage
}

\author{
Lee Jian Sian, Malina Jasamai, Nor Syafinaz Yaakob, Norsyahida Mohd Fauzi* \\ Drug and Herbal Research Centre, Faculty of Pharmacy, Universiti Kebangsaan Malaysia, Jalan Raja Muda Abdul Aziz 50300, \\ Kuala Lumpur, Malaysia
}

*For correspondence: Email: drnorsyahida@ukm.edu.my; Tel: +60-392898053

\begin{abstract}
Purpose: To investigate the inhibitory effects of a chalcone derivative on lipopolysaccharide (LPS)induced interleukin (IL)-6 and IL-8 secretions and on LPS-induced mitogen-activated protein kinases (MAPK) and nuclear factor kappa B (NF-KB) activation in human U937 macrophage-like cell line.

Methods: The effects of chalcone derivative on LPS-induced secretion of IL-6 and IL-8 in endothelial cells were determined by enzyme-linked immunosorbent assay while the effects of chalcone on the activation of MAPK and NF-kB pathway were determined by Western blotting.

Results: The results showed that 3-(5-methyl-furan-2-yl)-naphthalen-1-yl-propenone (compound 1) significantly inhibited the secretion of LPS-induced IL-6 and IL-8 in U937 macrophages. This compound also demonstrated significant suppression of c-Jun N-terminal kinases (JNK) and extracellular signalregulated kinases (ERK) phosphorylation. However, the compound did not reverse the degradation of inhibitor kappa B alpha (IKBa) and did not inhibit the phosphorylation of NF-KB subunit and P-38 MAPK. Conclusion: Compound 1 inhibits the secretion of cytokines via the inhibition of ERK and JNK pathways. These results suggest that chalcone derivative could act as an antiinflammatory agent by altering cytokine secretion and inflammatory pathways.
\end{abstract}

Keywords: Inflammation, Chalcone derivative, Cytokines, MAPK, NF-KB, Macrophage

\begin{abstract}
This is an Open Access article that uses a fund-ing model which does not charge readers or their institutions for access and distributed under the terms of the Creative Commons Attribution License (http://creativecommons.org/licenses/by/4.0) and the Budapest Open Access Initiative (http://www.budapestopenaccessinitiative.org/read), which permit unrestricted use, distribution, and reproduction in any medium, provided the original work is properly credited.

Tropical Journal of Pharmaceutical Research is indexed by Science Citation Index (SciSearch), Scopus, International Pharmaceutical Abstract, Chemical Abstracts, Embase, Index Copernicus, EBSCO, African Index Medicus, JournalSeek, Journal Citation Reports/Science Edition, Directory of Open Access Journals (DOAJ), African Journal Online, Bioline International, Open-J-Gate and Pharmacy Abstracts
\end{abstract}

\section{INTRODUCTION}

Inflammation is a crucial component of the complex biological response of body tissues against detrimental stimuli [1]. However, chronic and excessive inflammation will cause several diseases such as rheumatoid arthritis and atherosclerosis. Activated macrophages serve an important role in establishing inflammation by inducing the secretion of pro-inflammatory cytokines such as interleukin-6 (IL-6) and interleukin-8 (IL-8). IL-6 is a cytokine which induces neutrophil maturation as well as cytotoxic T-lymphocyte and natural killer cell differentiation [2]. Whilst IL-8 promotes chemotaxis and directs migration of leucocytes to the target site for immune responses [3].

Chalcones (1,3-diaryl-2-propen-ones) are $\alpha, \beta$ unsaturated ketones with two aromatic rings, 
which are present in edible fruits. These compounds serve their role as precursors in the biosynthesis of flavonoids and bioflavonoids. Chalcone derivatives from different moieties are synthesized in laboratories using the Claisen Schmidt condensation reaction [4]. Diverse pharmacological properties of chalcone derivatives including anti-proliferative, antiinflammatory and immunomodulatory have been demonstrated in previous studies [5-7]. Treatment with chalcone derivative known as cardamonin was reported to be able to inhibit LPS-induced TNF- $\alpha$ secretion in THP-1 cells [8]. Synthetic chalcone derivatives also inhibit polymorphonuclear neutrophils' (PMNs) chemotaxis as well as chemokines secretion induced by oxidised 1-palmitoyl-2-arachidonoylsn-glycero-3-phosphorylcholine (OxPAPC) in differentiated macrophage-like cells $[9,10]$. However, little is known whether they can also inhibit pro-inflammatory cytokine secretion induced by bacterial endotoxin. This study aimed to investigate the effects of a synthetic chalcone derivative on LPS-stimulated cytokines secretion in human U937 macrophages.

\section{EXPERIMENTAL}

\section{Chemicals and reagents}

Synthetic chalcone derivatives 3-(5-methyl-furan2-yl)-naphthalen-1-yl-propenone (Compound 1) (Figure 1) was obtained from the Drug and Herbal research Centre, Universiti Kebangsaan Malaysia and reported previously [23]. All cell culture reagents were purchased from Invitrogen (Burlington, ON, Canada). Lipopolysaccharides from Escherichia coli O26:B6 (LPS) was purchased from Sigma (St. Louis, MO, USA) and ELISA kits were purchased from eBioscience (San Diego, CA, USA). Antibodies for $p-E R K 1 / 2$, p-P38 and p-JNK were purchased from Cell Signaling Technology (Danvers, MA, USA) while antibody for IKBa, p-p65 and $\beta$-actin were purchased from Abcam (Cambridge, MA, USA). Other chemicals were purchased from Sigma (St. Louis, MO, USA) unless otherwise stated.

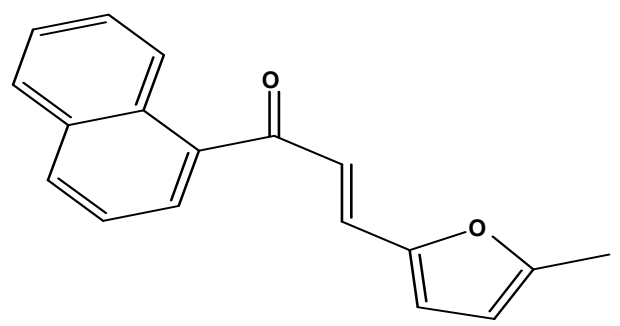

Figure 1: Chemical structures of 3-(5-methyl-furan-2yl)-naphthalen-1-yl-propenone

\section{Cell culture and cell differentiation}

The U937 mononuclear cell line was procured from ATCC (Manassas, VA, United States). The cells were maintained in RPMI-1640 and supplemented with $10 \%$ FBS, 100 units $/ \mathrm{mL}$ penicillin and $100 \mu \mathrm{g} / \mathrm{ml}$ streptomycin. Cells were incubated in a humidified atmosphere with $5 \%$ $\mathrm{CO} 2$ at $37^{\circ} \mathrm{C}$. They were subcultured in $75 \mathrm{~cm} 2$ culture flasks or seeded for experiments. Differentiation of cells were done at $70 \%$ confluence. Cells were differentiated into macrophage-like cells with phorbol myristate acetate (PMA) for 24 hours and followed with overnight incubation with serum-free media [11] before treated with compounds.

\section{Determination of cytokines secretion}

Compound 1 was dissolved in dimethylsulphoxide (DMSO) to prepare stock solution at a concentration of $50 \mathrm{mM}$. The stock solution was further diluted in serum-free media at concentrations of $12.5,25$, and $50 \mu \mathrm{M}$. To determine the effects of compound 1 on LPSinduced IL-6 and IL-8 secretion, cells were pretreated with the compound for $1 \mathrm{~h}$ and followed by stimulation with $1 \mu \mathrm{g} / \mathrm{mL}$ of LPS for the subsequent $24 \mathrm{~h}$. Duration for the induction of IL-6 and IL-8 with LPS was determined based on the findings from a preliminary work. A vehicle control group received $0.1 \% \mathrm{DMSO}$, a negative control group received LPS $(1 \mu \mathrm{g} / \mathrm{mL})$, a positive control group received a combination of dexamethasone and LPS and treatment groups received different concentrations of chalcone derivative and LPS. Supernatants were collected and enzyme-linked immunosorbent assay (ELISA) was carried out according to the manufacturer's instructions.

\section{Detection of protein expression by Western immunoblot}

To investigate the effects of compound 1 on the activation of MAPK and NF-kB pathway, Western blotting was used to determine the phosphorylation of ERK, JNK P-38, P65 and degradation of IkBa. Compound 1 at concentrations $12.5,25$ and $50 \mu \mathrm{M}$ was added into cells for $1 \mathrm{~h}$ and followed by the addition of LPS for $1 \mathrm{~h}$. Subsequently, cells lysate was prepared by adding lysis buffer that contain protease and phosphatase inhibitors. The concentration of protein was determined using Bradford assay. The cell lysate $(20 \mu \mathrm{g})$ was added in wells of sodium dodecyl sulphate polyacrylamide gel electrophoresis (SDS-PAGE). SDS-PAGE separates proteins primarily by mass because the ionic detergent SDS denatures and 
binds to proteins to make them uniformly negatively charged.

Subsequently, Western blotting technique was carried out as previously described [12]. Protein on the gel was transferred to polyvinylidene difluoride (PVDF) membrane. The membrane was blocked with $5 \%$ BSA and washed with TBST and followed with overnight incubation with primary antibodies such as p-ERK, p-JNK, pP38, p-p65, anti-ikBa (1:1000) or $\beta$-actin (1:5000). Subsequently, the membrane was washed and a secondary antibody (1:5000) was added onto the membrane for $1 \mathrm{~h}$. Enhanced chemiluminescence substrate (ECL) (Perkin Elmer, USA) was added onto the membrane to visualise the bands and the relative intensity was quantified using Fusion-Capt Advance Software (Vilber Loumat, Germany).

\section{Statistical analysis}

The data were collected from three replicates of experiments and subjected to analysis using GraphPad Prism 5 software (GraphPad Software Inc, San Diego, CA, USA). The data are presented as mean \pm standard error of mean (SEM). Mean differences between groups were assessed using one-way analysis of variance (ANOVA) followed by Bonferroni post-hoc test. $P$ $<0.05$ was considered statistically significant.

\section{RESULTS}

Inhibitory effects of compound 1 on LPSinduced cytokines secretion

Concentrations of compound 1 used in this study were selected based on the concentrations that did not cause more than 10\% U937 macrophage cell death, as reported in our previous work [10]. Figure 2 A shows the effect of compound 1 on LPS-induced IL-6 secretion in U937. The secretion of IL- 6 by LPS-stimulated cells was significantly increased in cells treated with LPS at a concentration of $1 \mu \mathrm{g} / \mathrm{mL}$. Dexamethasone (100 nM) significantly diminished IL-6 secretion induced by LPS.

Chalcone derivative $(12.5 \mu \mathrm{M})$ significantly inhibited IL-6 secretion $(p<0.01)$ and further reduction was observed in cells treated with chalcone derivative at 25 and $50 \mu \mathrm{M}(p<0.001)$. The percentage of inhibition by the highest concentration used in this study was $36.095 \%$. Figure $2 \mathrm{~B}$ shows the effect of compound 1 on LPS-induced IL-8 secretion in U937 cells. A significant increase of IL-8 secretion was observed in cells treated with LPS. Dexamethasone significantly inhibited IL-8 secretion and chalcone derivative inhibited IL-8 secretion in a concentration dependent manner.
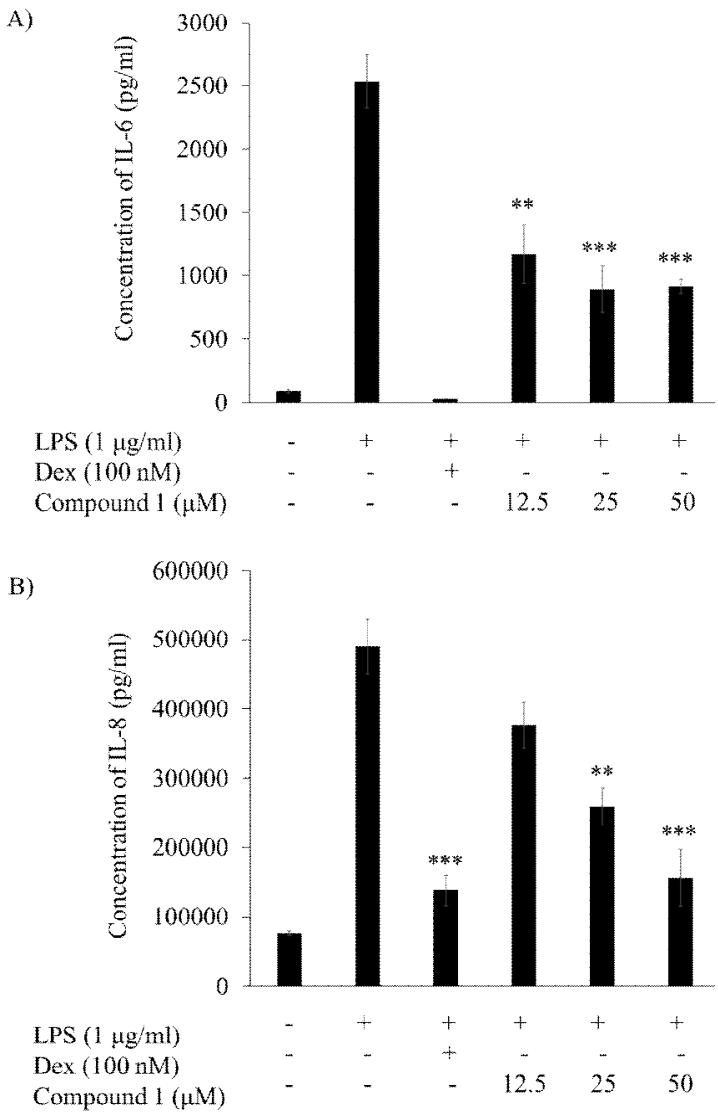

Figure 2: Effects of compound 1 on LPS-induced (A) IL-6 and (B) IL-8 secretion in U937 macrophage was determined using ELISA. Cells were pre-treated with chalcone derivative for $1 \mathrm{~h}$ followed by induction with LPS at $1 \mu \mathrm{g} / \mathrm{mL}$ for $24 \mathrm{~h}$. The data presented are mean \pm SEM $(\mathrm{n}=3) ;{ }^{* *} p<0.01,{ }^{* *} p<0.001$ vs negative control

\section{Compound 1 did not suppress LPS-induced IKBa degradation and p65 phosphorylation}

Figure $3 \mathrm{~A}$ shows that compound 1 did not inhibit the NFKB pathway. Following treatment with LPS, degradation of IKBa was observed. However, treatment of cells with compound 1 at concentrations ranging from 12.5 to $50 \mu \mathrm{M}$ did not reverse the degradation of IKBa. Similarly, treatment with LPS was found to increase phosphorylation of phospho-p65. However, the chalcone derivative did not significantly suppress the phosphorylation of p65 NFKB although there was a trend for a reduction of phosphorylation. The intensity of each band was normalised with respect to beta-actin protein expression while statistical analysis was carried out with respect to negative control. 


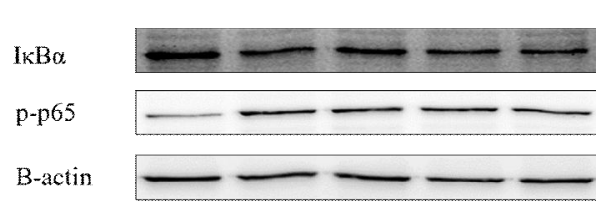

A)

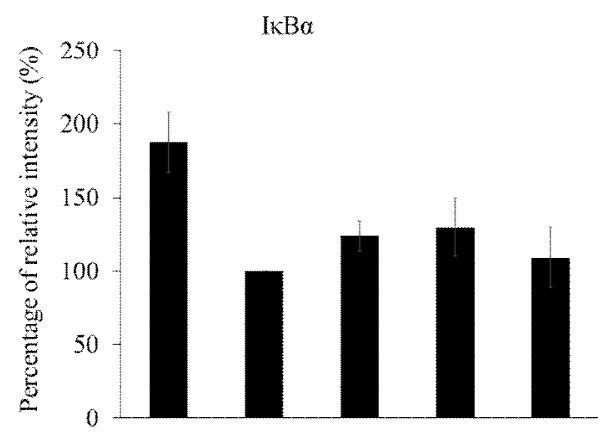

LPS $(1 \mu \mathrm{g} / \mathrm{ml})$

Compound $1(\mathrm{uM})$

B)

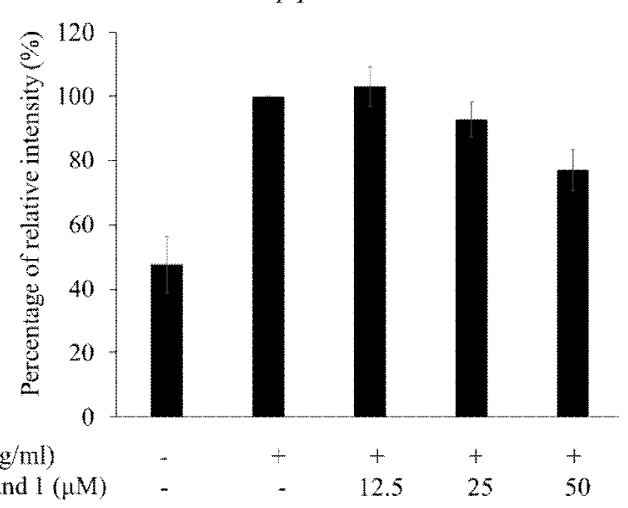

Figure 3: Effect of chalcone derivative on LPSinduced A) $\mathrm{IKBa}$ degradation and (B) p-p65 expression. Cells were pre-treated with chalcone derivatives for $1 \mathrm{~h}$ prior to stimulation with LPS at 1 $\mu \mathrm{g} / \mathrm{mL}$ for $60 \mathrm{~min}$. The data represented mean \pm SEM $(\mathrm{n}=3)$

\section{Compound 1 suppressed LPS-induced ERK and JNK phosphorylation but did not inhibit p-38}

Figure 4 shows that compound 1 may inhibit phosphorylation of ERK and JNK but not p38. Following treatment with LPS, significant increase in expression of the three MAPKs was observed. Pretreatment with compound 1 reduced the phosphorylation of ERK back to normal level starting from $25 \mu \mathrm{M}$ (Figure $4 \mathrm{~A}$ ). Whilst for phosphorylation of JNK, significant reduction of phosphorylation was observed in cells pretreated with $25 \mu \mathrm{M}$ of compound 1 but a reduction to normal level was observed in cells pretreated with $50 \mu \mathrm{M}$ of compound 1 (Figure 4 B). Moreover, this compound did not inhibit the phosphorylation of P38 MAPK signalling pathway (Figure $4 \mathrm{C}$ ).

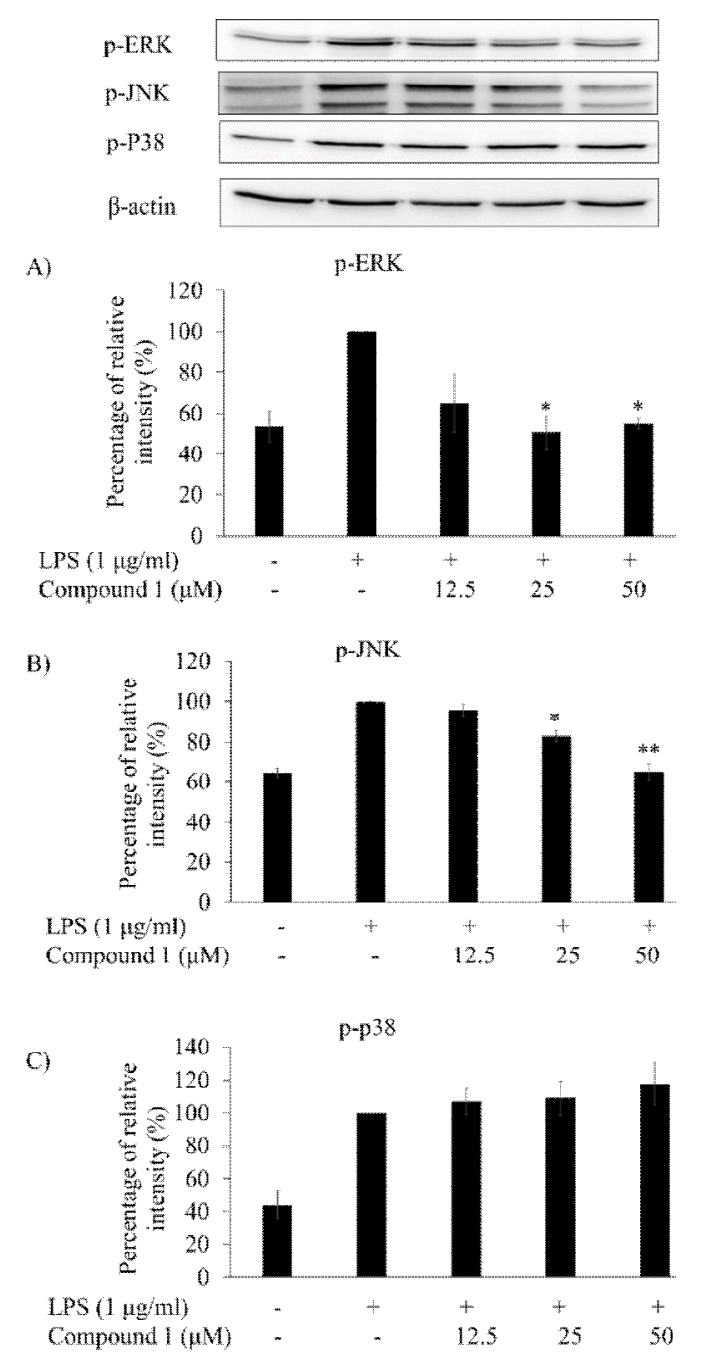

Figure 4: Effects of chalcone derivative on LPSinduced A) p-ERK, (B) p-JNK and C) p-P38 MAPK expression. Cells were pre-treated with chalcone derivatives for 1 hour prior to stimulation with LPS at 1 $\mu \mathrm{g} / \mathrm{mL}$ for $60 \mathrm{~min}$. The data represented mean \pm SEM $(\mathrm{n}=3)$

\section{DISCUSSION}

LPS is a distinctive glycolipid comprising of a highly variable carbohydrate segment and a unique lipid $A$ region, which can be found in the outer wall of Gram-negative bacteria [13]. A previous study reported that the presence of LPS at $50 \mathrm{pg} / \mathrm{mL}$ or above in the plasma may increase the risk of developing atherosclerosis in humans [14]. This molecule is known to be a pathogen-associated microbial pattern (PAMP) which may activate Toll-like receptor (TLR) signalling to demonstrate cellular responses such as the secretion of interferon and proinflammatory cytokines [15]. A study conducted by Clahsen and Schaper revealed that the role of IL-6 as the pro-inflammatory cytokine by promoting monocytic cell migration through a number of processes such as integrin activation, 
cell attachment, polymerisation of actin, chemotaxis and fibronectin-dependent migration [16]. IL-8 was also demonstrated to cause attachment of monocytic cells to human atherosclerotic plaques [17].

The present study found that compound 1 significantly suppressed LPS-induced IL-6 and IL-8 secretion in human U937 macrophages. This result is consistent with previous data that reported the inhibitory effects of natural chalcone and chalcone derivatives on proinflammatory cytokines secretion. Several natural chalcones have been demonstrated to inhibit proinflammatory cytokines secretion. For instance, naringenin caused significant inhibition on LPS induced IL-1 $\beta$, IL-6, TNF- $\alpha$ and IL-8 secretion stimulated by LPS in macrophage cells [18]. Moreover, butein, a natural chalcone, was found to attenuate the secretion of IL-6, IL-8 and TNF- $\alpha$ induced by calcium ionophore A23187 (PMACI) in human mast cells [19]. A chalcone derivative, trans-1,3-diphenyl-2,3-epoxypropane1-one (DPEP) has shown that it is able to inhibit LPS-induced IL-6, IL-1 $\beta$ and TNF- $\alpha$ secretion in murine RAW264.7 cells in a concentrationdependent manner [20]. In the present study, compound 1 exhibited significant inhibition on LPS-induced IL-6 and IL-8 secretion, possibly due to the presence of naphthalene and methyl furan groups in the compound. Consistent with our findings, a synthetic hydroxypropenone bearing methyl furan group demonstrated that it is able to alleviate the secretion of IL-1 $\beta$, TNF- $\alpha$ and IL- 6 as well as prostaglandin induced by LPS in murine RAW264.7 cells [11]. Moreover, it has been demonstrated previously that compound 1 can also inhibit proinflammatory cytokines secretion induced by oxidised phospholipids [10]. Oxidised phospholipids such as OxPAPC did not produce cytokines particularly MCP-1 and IL-8 through common inflammatory pathways that include NF-kB and MAPK, suggesting that this compound may affect cytokine secretion by targeting various types of signalling pathways.

NFKB comprises of a family of transcription factors which are essential to control inflammation, immune responses, and several cellular processes (survival, differentiation, and proliferation). In resting cells, inactive $N F K B$ is held as dimers in the cytoplasm and are associated with a regulatory element known as inhibitory kappa B (IKB) proteins. Upon stimulation, activated IKB kinase complex will cause phosphorylation, ubiquitination, and subsequent IKB proteins degradation to release NFKB. This is followed by translocation of NFKB to the nucleus and initiation of transcription for target genes [21]. In the present study, we showed that the induction with LPS at $1 \mu \mathrm{g} / \mathrm{mL}$ caused significant phosphorylation of NFKB p65 protein and degradation of $\mathrm{I} \mathrm{KB \alpha}$ protein. Treatment with compound 1 inhibited neither the phosphorylation of NFKB p65 proteins nor the degradation of $\mathrm{I} \mathrm{BB} \alpha$ proteins. In contrast, Ban and colleagues reported the inhibitory potential of 2'-hydroxy chalcone derivatives which may inhibit I $\mathrm{kB} \alpha$ degradation and attenuate the activation of transcription factors, NFKB and AP-1 [22]. 2',4dihydroxy-6'-isopentyloxychalcone (JSH) was demonstrated to bind competitively on MD-2, a subunit of the receptor complex for LPS, thus preventing the activation of NFKB pathways [23].

MAPKs are serine/threonine protein kinases which function as key regulators of diverse cellular processes such as gene induction, cell survival, proliferation, differentiation, and inflammation. Conventional MAPKs consist of the extracellular signal-regulated kinases $1 / 2$ (ERK1/2), c-Jun amino (N)-terminal kinases 1/2/3 (JNK1/2/3), P38 isoforms ( $\alpha, \beta, \mathrm{Y}$, and $\delta$ ) and ERK5. Activation of MAPK signaling pathways involves three sequentially activated kinases: a MAPK, a MAPK kinase (MAPKK) and a MAPKK kinase (MAPKKK), which are triggered by a phosphorylation cascade upon exposure to stimuli [24]. DPEP was reported to inhibit phosphorylation of p38, ERK and JNK MAPKs induced by LPS in RAW264.7 cells [32]. A chalcone isolated from the heartwood of Pterocarpus marsupium, a-dihydroxychalconeglycoside $(\alpha-D H C)$, markedly suppressed LPSinduced phosphorylation of the three protein kinases in RAW264.7 cells [25]. In the present study pre-treatment of the cells with compound 1 did not inhibit phosphorylation of the P38 MAPK pathways. However, it can cause remarkable inhibition of JNK and ERK MAPKs phosphorylation. This suggests that compound 1 might exert its inhibitory effect on LPS-mediated cytokines secretion by suppressing ERK and JNK MAPKs pathways but not cytosolic NFKB signalling pathways.

\section{CONCLUSION}

The present findings reveal that compound 1 exhibits potential anti-inflammatory property by significantly reducing LPS-induced proinflammatory cytokines secretion in U937 macrophages. The underlying mechanism of this inhibitory potential is most likely caused by suppressing the phosphorylation of ERK and JNK MAPK signaling pathways. These results suggested that chalcone derivative could act as the antiinflammatory agents by altering cytokine secretion and inflammatory pathways. 


\section{DECLARATIONS}

\section{Acknowledgement}

This study was supported by the Malaysian Ministry of Higher Education (MOHE) through the Fundamental Research Grant Scheme (Grant no. FRGS/2/2013/SKK01/UKM/03/7).

\section{Conflict of interest}

No conflict of interest is associated with this work.

\section{Contribution of authors}

We declare that this work was done by the authors named in this article and all liabilities pertaining to claims relating to the content of this article will be borne by the authors. The experimental design of the study was conducted by Norsyahida Mohd Fauzi, Malina Jasamai Norazrina Azmi, Endang Kumolosasi and Nor Syafinaz Yaakob. The synthesis of chalcone derivatives was synthesised by Malina Jasamai and the bioassays were carried out by Lee Jian Sian.

\section{Open Access}

This is an Open Access article that uses a funding model which does not charge readers or their institutions for access and distributed under the terms of the Creative Commons Attribution License (http://creativecommons.org/licenses/by/ 4.0) and the Budapest Open Access Initiative (http://www.budapestopenaccessinitiative.org/rea d), which permit unrestricted use, distribution, and reproduction in any medium, provided the original work is properly credited.

\section{REFERENCES}

1. Nathan C. Points of control in inflammation. Nature 2002; 420(6917): 846-852.

2. de Oliveira $C M B$, Sakata RK, Issy $A M$, Gerola $L R$, Salomão R. Cytokines and pain. Rev Bras Anestesiol 2011; 61(2): 255-265.

3. Brat DJ, Bellail AC, Van Meir EG. The role of interleukin8 and its receptors in gliomagenesis and tumoral angiogenesis. Neuro Oncol 2005; 7(2): 122-133.

4. Bukhari SNA, Jasamai M, Jantan I, Ahmad W. Review of methods and various catalyst used for chalcones synthesis. Mini Rev Org Chem 2013; 10(1): 73-83.

5. Wei H, Zhang X, Wu G, Yang X, Pan S, Wang Y, Ruan J. Chalcone derivatives from the fern Cyclosorus parasiticus and their anti-proliferative activity. Food Chem Toxicol 2013; 60: 147-152.

6. Bandgar BP, Gawande SS. Synthesis and biological screening of a combinatorial library of b-chlorovinyl chalcones as anticancer, anti-inflammatory and antimicrobial agents. Bioorg Med Chem 2010; 18(5): 2060-2065.

7. Lee JS, Bukhari SNA, Mohd Fauzi N. Effects of chalcone derivatives on players of the immune system. Drug Des Devel Ther 2015; 9: 4761-4778.

8. Hatziieremia S, Gray Al, Ferro VA, Paul A, Plevin R. The effects of cardamonin on lipopolysaccharide-induced inflammatory protein production and MAP kinase and $N F K B$ signalling pathways in monocytes/macrophages. Br J Pharmacol 2006; 149(2): 188-198.

9. Bukhari SNA, Tajuddin Y, Benedict VJ, Lam KW, Jantan I, Jalil J, Jasamai M. Synthesis and evaluation of chalcone derivatives as inhibitors of neutrophils' chemotaxis, phagocytosis and production of reactive oxygen species. Chem Biol Drug Des 2014; 83(2): 198206.

10. Sock-Jin L, Kumolosasi E, Azmi N, Bukhari SNA, Jasamai M, Fauzi NM. Effects of synthetic chalcone derivatives on oxidised palmitoyl arachidonoyl phosphorylcholine-induced proinflammatory chemokines production, RSC Adv 2015; 5(84): 68773-68780.

11. Liew CY, Tham CL, Lam KW, Mohamad AS, Kim MK, Cheah YK, Zakaria ZA, Sulaiman MR, Lajis $N H$, Israf $D A$. A synthetic hydroxypropenone inhibits nitric oxide, prostaglandin E2, and proinflammatory cytokine synthesis. Immunopharmacol Immunotoxicol 2010; 32(3): 495-506.

12. Park $P H$, Kim HS, Jin $X Y$, Jin F, Hur J, Ko G, Sohn $D H$. $K B-34$, a newly synthesized chalcone derivative, inhibits lipopolysaccharide-stimulated nitric oxide production in RAW 264.7 macrophages via heme oxygenase-1 induction and blockade of activator protein-1. Eur $J$ Pharmacol 2009; 606(1-3): 215-224.

13. Stoll LL, Denning GM, Weintraub NL. Potential role of endotoxin as a proinflammatory mediator of atherosclerosis. Arterioscler Thromb Vasc Biol 2004; 24(12): 2227-2236.

14. Wiedermann CJ, Kiechl $S$, Dunzendorfer $S$, Schratzberger P, Egger G, Oberhollenzer F, Willeit J. Association of endotoxemia with carotid atherosclerosis and cardiovascular disease: Prospective results from the Bruneck Study. J Am Coll Cardiol 1999; 34(7): 1975-1981.

15. Brightbill HD, Modlin RL. Toll-like receptors: Molecular mechanisms of the mammalian immune response. Immunology 2000; 101(1): 1-10.

16. Clahsen T, Schaper F. Interleukin-6 acts in the fashion of a classical chemokine on monocytic cells by inducing integrin activation, cell adhesion, actin polymerization, chemotaxis, and transmigration. J Leukoc Biol 2008; 84(6): 1521-1529.

17. Papadopoulou C, Corrigall V, Taylor PR, Poston RN. The role of the chemokines MCP-1, GRO- $\alpha, I L-8$ and their 
receptors in the adhesion of monocytic cells to human atherosclerotic plaques. Cytokine 2008; 43(2): 181-186.

18. Bodet C, La VD, Epifano F, Grenier D. Naringenin has anti-inflammatory properties in macrophage and ex vivo human whole-blood models. J Periodontal Res 2008; 43(4): 400-407.

19. Rasheed Z, Akhtar N, Khan A, Khan KA, Haqqi TM. Butrin, isobutrin, and butein from medicinal plant Butea monosperma selectively inhibit nuclear factor-kappaB in activated human mast cells: suppression of tumor necrosis factor-alpha, interleukin (IL)-6, and IL-8. J Pharmacol Exp Ther 2010; 333(2), 354-363.

20. Kim KN, Ko YJ, Kang MC, Yang HM, Roh SW, Oda T, Jeon YJ. Jung WK, Heo SJ, Yoon WJ, Kim D. Antiinflammatory effects of trans-1,3-diphenyl-2,3epoxypropane-1-one mediated by suppression of inflammatory mediators in LPS-stimulated RAW 264.7 macrophages. Food Chem Toxicol 2013; 53: 371-375.

21. Hayden MS, Ghosh S, Hayden MS, Ghosh S. NF-kB, the first quarter-century: remarkable progress and outstanding questions. Genes Dev 2012; 26(3): 203234.
22. Ban HS, Suzuki K, Lim SS, Jung SH, Lee S, Ji J, Lee HS, Lee YS, Shin KH, Ohuchi K. Inhibition of lipopolysaccharide-induced expression of inducible nitric oxide synthase and tumor necrosis factor-alpha by 2'hydroxychalcone derivatives in RAW 264.7 cells., Biochem Pharmacol 2004; 67(8): 1549-1557.

23. Roh E, Lee H, Kwak J, Hong JT, Nam S, Jung S, Lee JY, Kim ND, Han S, Kim Y. MD-2 as the target of nonlipid chalcone in the inhibition of endotoxin LPS-induced TLR4 activity. J Infect Dis 2011; 203(7): 1012-1020.

24. Cargnello M, Roux PP. Activation and function of the MAPKs and their substrates, the MAPK-activated protein kinases. Microbiol Mol Biol Rev 2011; 75(1): 5083.

25. Chakraborty $P$, Saraswat G, Kabir SN. aDihydroxychalcone-glycoside $(\alpha-D H C)$ isolated from the heartwood of Pterocarpus marsupium inhibits LPS induced MAPK activation and up regulates $\mathrm{HO}-1$ expression in murine RAW 264.7 macrophage. Toxicol Appl Pharmacol 2014; 277(1): 95-107. 